\title{
Effect of the oxidation state of gold on the complete oxidation of isobutane on $\mathrm{Au} / \mathrm{CeO}_{2}$ catalysts
}

\author{
Fang Ying ${ }^{a}$, Shuiju Wang ${ }^{b}$, Chak-Tong $\mathrm{Au}^{\mathrm{a}}$ and Suk-Yin Laj ${ }^{\mathrm{a},{ }^{*}}$ \\ www.goldbulletin.org
}

\begin{abstract}
Catalysts of highly dispersed gold supported on ceria were prepared by deposition precipitation method. $\mathrm{Au}$ is dispersed as $\mathrm{Au}^{0}, \mathrm{Au}^{+}$and $\mathrm{Au}^{3+}$ species on ceria. The content of $\mathrm{Au}^{+}$and $\mathrm{Au}^{3+}$ was highest on catalyst prepared on uncalcined ceria, which possess least ordered surface. It is inferred that oxygen vacancy on disordered ceria surface is essential for the preparation of highly dispersed gold catalysts and in stabilizing monolayer surface $\mathrm{Au}^{+}$clusters while cationic vacancies are sites for substitutional $\mathrm{Au}^{3+}$. $\mathrm{Au} / \mathrm{CeO}_{2}$ catalysts showed low-temperature isobutane oxidation activity with maximum conversion at $150-180^{\circ} \mathrm{C}$. Ex-situ XPS results demonstrated that the low temperature isobutane oxidation activity was closely related to the content of $\mathrm{Au}^{+}$which we interpreted as surface gold oxide formed under reaction conditions. Isobutane oxidation activity associated with ceria at temperature above $300^{\circ} \mathrm{C}$ was enhanced by substitutional $\mathrm{Au}^{3+}$.
\end{abstract}

\section{Introduction}

$\mathrm{Au} / \mathrm{CeO}_{2}$ catalysts have been found to exhibit high activity in various reactions, one of the most intensively studied is the complete oxidation of volatile organic compounds (VOCs) (1-8). The catalytic activity depends mainly on the morphology of ceria particles, gold particle size and the oxidation state of gold species. In general, nanosize gold particles with diameter less than $5 \mathrm{~nm}$ supported on nanocrystalline $\mathrm{CeO}_{2}$ have been demonstrated for high activity in VOCs oxidation reactions $(1,5,6)$.

Despite numerous studies, the nature of the gold species in active VOCs oxidation catalysts is still under debate. The participation of cationic gold in reactions over gold catalysts has been discussed quite widely (7-10). Shen et al. found that $\mathrm{Au} / \mathrm{CeO}_{2}$ catalyst with highly dispersed metallic gold and small amount of oxidized gold exhibited superior catalytic activity for $\mathrm{HCHO}$ oxidation (7). Likewise, Liu et al. reported that $\mathrm{Au} / \mathrm{CeO}_{2}$ calcined at $300^{\circ} \mathrm{C}$ exhibited high content of cationic gold species and excellent activity for 2-propanol complete oxidation (8). The results stimulated much study on the nature of gold on ceria, both experimentally and theoretically and have provided important insight into the interaction between gold and ceria. Based on results of density functional theory calculation, Liu et al. deduced that $\mathrm{O}$ vacancies act as anchoring sites for $\mathrm{Au}$, and a Au atom adsorbed on an $\mathrm{O}$ vacancy is negatively charged and is inactive in binding $\mathrm{CO}$. Other gold atoms bound to this kind of anchored atoms, forming a monolayer gold cluster, are positively charged through electron transfer to the $f$ orbitals of cerium (11). The more recent DFT+U calculation of Camelone and Fabris also predicted that Au atoms on $\mathrm{O}$ vacancies to be negatively charged while $\mathrm{Au}$ atom supported on stoichiometric $\mathrm{CeO}_{2}(111)$ to be $\mathrm{Au}^{+}$. These authors also deduced that $\mathrm{Au}$ atoms substituted for cerium in the $\mathrm{CeO}_{2}(111)$ lattices
Department of Chemistry and Centre for Surface Analysis Hong Kong, China

b State Key Laboratory for Physical Chemistry of Solid Surface, Xiamen University, Xiamen, 361005, China

* Corresponding author

E-mail: laisy@hkbu.edu.hk 
have charge corresponding to the $\mathrm{Au}^{3+}$ state. The substitutional gold ions cause distortion of the surrounding lattices and are highly active for $\mathrm{CO}$ oxidation (12). Experimentally, partial reduction of cerium from $\mathrm{Ce}^{4+}$ to $\mathrm{Ce}^{3+}$ by deposition of gold on $\mathrm{CeO}_{2}(111)$ was demonstrated by Skoda et al. using resonant photoelectron spectroscopy (13). Using STM and RAIRS of CO adsorption on gold, Naya et al. showed that positively charged gold was formed when gold was deposited on $\mathrm{CeO}_{2}(111)$ surfaced with oxygen vacancies while gold deposited on the stoichiometric surface is uncharged (14). In a different study on the interaction of atomic oxygen with $\mathrm{Au}(111)$ using DFT calculation, Shi and Stampfl predicted that a surface gold oxide phase should be stable up to $420 \mathrm{~K}$ at atmospheric pressure of oxygen. They suggested that surface gold oxide can play a significant role in the catalysis by gold (15).

The present study focused on the preparation of $\mathrm{Au} / \mathrm{CeO}_{2}$ with high fraction of cationic gold species by the deposition-precipitation method and the identification of the active centers in the complete oxidation of light alkanes, using isobutane as a test compound.

\section{Experimental}

Nanocrystalline $\mathrm{CeO}_{2}$ was prepared by first dissolving $5 \mathrm{~g} \mathrm{Ce}\left(\mathrm{NO}_{3}\right)_{3} \cdot 6 \mathrm{H}_{2} \mathrm{O}$ in $100 \mathrm{~mL}$ D.I. $\mathrm{H}_{2} \mathrm{O}$ under ultrasonication, then $0.005 \mathrm{~g} / \mathrm{mL} \mathrm{NaOH}$ aqueous solution was added gradually with vigorous stirring during the ultrasonication until the $\mathrm{pH}$ value was 10 . The mixture became a light purple colloid. After $1 \mathrm{~h}$ further ultrasonication, the precipitate was centrifuged out and the recovered $\mathrm{CeO}_{2}$ was washed three times with D.I. water. The obtained product was divided into three portions. One portion was simply dried at $100^{\circ} \mathrm{C}$ whereas the others were calcined in air at 300 or $500^{\circ} \mathrm{C}$ for $4 \mathrm{~h}$. The samples are denoted hereinafter as $\mathrm{CeO}_{2}-100, \mathrm{CeO}_{2}-300$ and $\mathrm{CeO}_{2}-500$ respectively.

Gold was loaded onto the $\mathrm{CeO}_{2}$ samples by deposition-precipitation by stirring ceria powders in a solution of chloroauric acid in deionized water at $\mathrm{pH} 10$ for $5 \mathrm{~h}$ at room temperature. Then the suspension was filtered out and washed several times with D.I. water. Finally, the obtained sample was dried at $100^{\circ} \mathrm{C}$ for $12 \mathrm{~h}$ and calcined at $300^{\circ} \mathrm{C}$ for $4 \mathrm{~h}$. The so-obtained catalysts are denoted as $\mathrm{Au} / \mathrm{CeO}_{2}-100, \mathrm{Au} / \mathrm{CeO}_{2}-300$ and $\mathrm{Au} / \mathrm{CeO}_{2}-500$.
X-ray diffraction (XRD) analysis was conducted on a Rigaku D-MAX diffractometer with Ni-filtered Cu $\mathrm{K} \alpha$ radiation. $\mathrm{N}_{2}$ adsorption-desorption isotherms were recorded on a Quantachrome NOVA-1200 instrument. ICP-AES using a Perkin-Elmer Optima 3000 spectrometer was applied to determine the gold content of the catalysts. The catalyst surface compositions were determined by X-ray photoelectron spectroscopy (XPS) over a Leybold Heraeus-Shengyang SKL-12 electron spectrometer equipped with a VG CLAM 4 MCD electron energy analyzer, using $\mathrm{Al}-\mathrm{K} \alpha$ as excitation source. Highresolution transmission electron microscopy (HRTEM) investigation was performed on a JEOL TEM-2100 operating at $200 \mathrm{kV}$.

$\mathrm{H}_{2}$-temperature programmed reduction $\left(\mathrm{H}_{2}-\mathrm{TPR}\right)$ was performed in a flow reaction system using a $5 \% \mathrm{H}_{2}$ in $\mathrm{N}_{2}$ mixture with flow rate of $50 \mathrm{~mL} \mathrm{~min}^{-1}$. Hydrogen consumption was monitored by a GowMac thermal conductivity detector with prior removal of water vapor by means of a liquid- $\mathrm{N}_{2}$ cold trap. The samples were oxidized in a flow of synthetic air with flow rate $25 \mathrm{~mL} \mathrm{~min}^{-1}$ at $300^{\circ} \mathrm{C}$ for 60 min before TPR experiment. Quantity of hydrogen consumption and hence degree of reduction of ceria after reduction to different temperature was determined by calibration with the reduction of a known amount of $\mathrm{CuO}$. With the $\mathrm{CeO}_{2}-100$ sample, an additional run on a fresh sample without pre-oxidation at $300^{\circ} \mathrm{C}$, denoted as $\mathrm{CeO}_{2}-100^{*}$, was performed. The reduction behavior of this sample is considered more representative of the surface property of $\mathrm{CeO}_{2}-100$ support used for the preparation of $\mathrm{Au} / \mathrm{CeO}_{2}-100$.

Isobutane oxidation was carried out in a fixedbed flow reactor at atmospheric pressure. In each run, $0.2 \mathrm{~g}$ of catalyst (80-40 mesh) was loaded in a quartz tubular reactor (8-mm i.d.) and activated in synthetic air at $300^{\circ} \mathrm{C}$ for $2 \mathrm{~h}$ before reaction. Then $1 \%$ isobutane in synthetic air at a flow rate of $50 \mathrm{~mL} / \mathrm{min}$ was passed over the catalyst at designated temperature, and the products were analyzed on-line with a Shimadzu 8A gas chromatograph with a methanizer and flame ionization detector.

\section{Results and discussion}

3.1 Morphological and textural characterization The specific surface area of the $\mathrm{CeO}_{2}$ samples decreased only slightly from 88 to $72 \mathrm{~m}^{2} \mathrm{~g}^{-1}$ with increasing calcination temperatures from 100 to $500^{\circ} \mathrm{C}$. Addition of gold did not change the catalyst surface area significantly. 


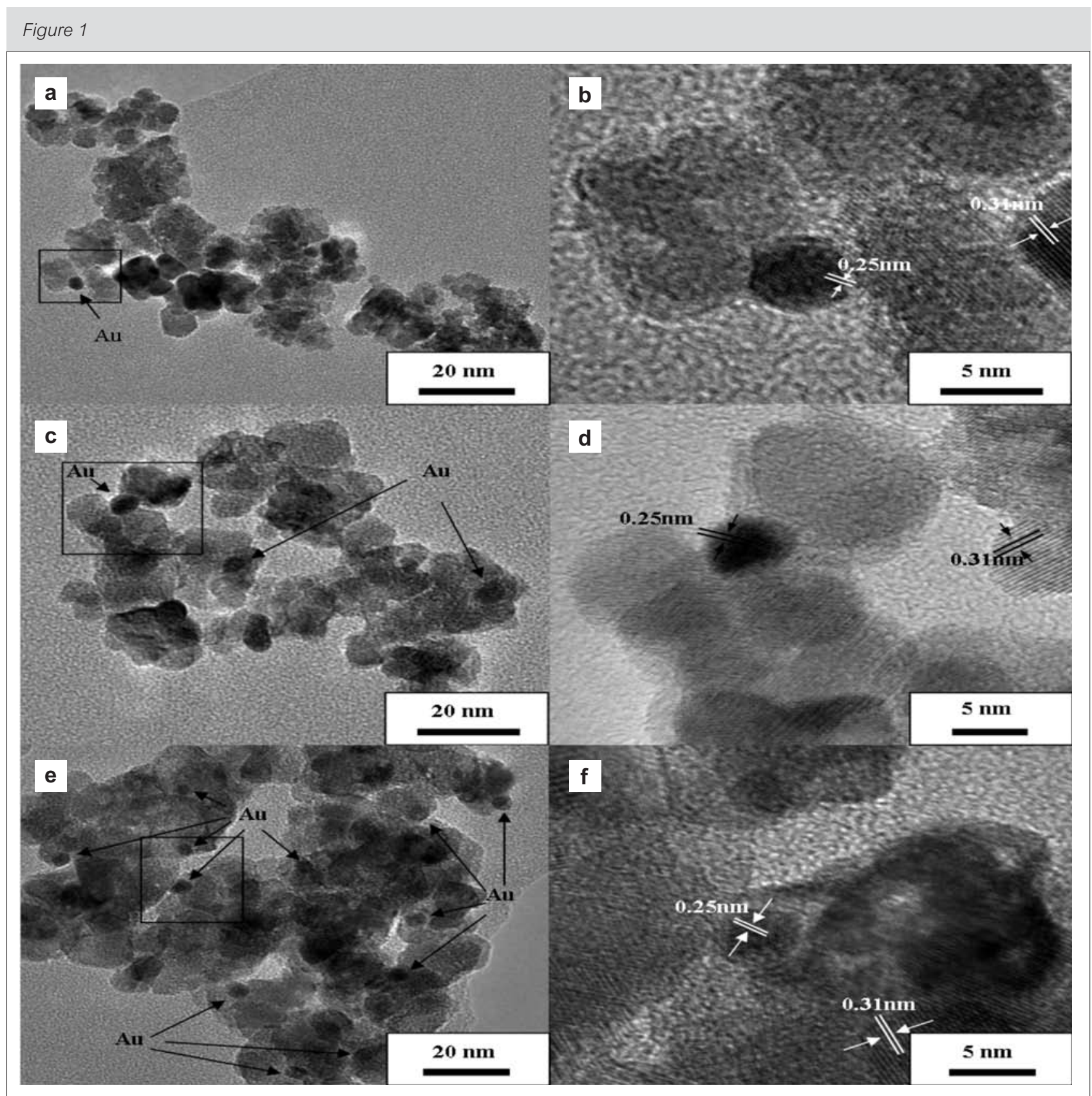

HRTEM of different Au-containing catalysts: (a,b) $\mathrm{Au} / \mathrm{CeO}_{2}-100 ;(c, d) \mathrm{Au} / \mathrm{CeO}_{2}-300 ;(e, f) \mathrm{Au} / \mathrm{CeO}_{2}-500$

The mean size of crystalline $\mathrm{CeO}_{2}$, calculated from the broadening of the (111) X-ray diffraction line using the Scherrer equation, was in the narrow range of 10.6 to $12.2 \mathrm{~nm}$, suggesting that sintering was not significant up to $500^{\circ} \mathrm{C}$, in agreement with the surface area data. X-ray diffraction peaks attributable to gold could hardly be detected over any of the gold-loaded samples showing that gold was highly dispersed. The gold loading of all the $\mathrm{Au} / \mathrm{CeO}_{2}$ catalysts obtained from ICP-AES results were in a narrow range of $1.7-1.9 \mathrm{wt} \%$.
Representative HRTEM images of $\mathrm{Au} / \mathrm{CeO}_{2}$ are shown in Figure 1. Figures 1(a), 1(c) and 1(e) are images at nominal magnifications from $\times 100,000$ to $\times 200,000$ showing the general features of the samples. Selected areas of the sample indicated were studied in higher magnification and shown in Figures 1(b), 1(d) and 1(f) to show the crystal lattice fringes. $\mathrm{Au} / \mathrm{CeO}_{2}-100, \mathrm{Au} / \mathrm{CeO}_{2}-300$ and $\mathrm{Au} / \mathrm{CeO}_{2}-500$ contained discrete crystalline $\mathrm{CeO}_{2}$ particles with the size of 10 to $12 \mathrm{~nm}$ in agreement with the XRD results. Although the $\mathrm{CeO}_{2}$ samples were 
Table 1: XPS results of catalysts

\begin{tabular}{|c|c|c|c|c|c|c|c|}
\hline \multirow[t]{2}{*}{ Catalyst } & \multicolumn{3}{|c|}{ Surface composition } & \multirow{2}{*}{$\begin{array}{l}\text { Position of } \\
\text { Au } \mathbf{4 f}_{7 / 2} \text { peak } \\
\text { Binding } \\
\text { Energy } \\
(\mathrm{eV})\end{array}$} & \multicolumn{3}{|c|}{ Au species distribution ${ }^{a}$} \\
\hline & $\begin{array}{l}\mathrm{Au} \\
(\mathrm{mol} \%)\end{array}$ & $\begin{array}{l}\mathrm{Ce} \\
(\mathrm{mol} \%)\end{array}$ & $\begin{array}{l}\mathrm{O} \\
(\mathrm{mol} \%)\end{array}$ & & $\begin{array}{l}\mathrm{Au}^{0} \\
(\%)\end{array}$ & $\begin{array}{l}\mathrm{Au}^{+} \\
(\%)\end{array}$ & $\begin{array}{l}\mathrm{Au}^{3+} \\
(\%)\end{array}$ \\
\hline $\mathrm{CeO}_{2}-100$ & - & 22.1 & 77.9 & - & & - & - \\
\hline $\mathrm{CeO}_{2}-300$ & - & 26.6 & 73.4 & - & & - & - \\
\hline $\mathrm{CeO}_{2}-500$ & - & 27.1 & 72.9 & - & & - & - \\
\hline $\mathrm{Au} / \mathrm{CeO}_{2}-100$ & 0.5 & 28.4 & 71.1 & 84.6 & 13.0 & 50.1 & 36.9 \\
\hline $\mathrm{Au} / \mathrm{CeO}_{2}-300$ & 0.4 & 28.6 & 71.0 & 83.8 & 60.7 & 18.6 & 20.7 \\
\hline $\mathrm{Au} / \mathrm{CeO}_{2}-500$ & 0.5 & 28.6 & 70.9 & 83.6 & 71.8 & 15.8 & 12.4 \\
\hline
\end{tabular}

calcined at different temperatures, no significant difference in $\mathrm{CeO}_{2}$ particle size and morphologies was found among the three samples.

Gold particles with lattice spacing of $0.25 \mathrm{~nm}$ can be detected in all the three gold-containing samples. It should be pointed out that gold particles with a diameter of ca. $4 \mathrm{~nm}$ were only occasionally detected in $\mathrm{Au} / \mathrm{CeO}_{2}-100$. Most dark particles such as the one shown at the right edge of figure $1(\mathrm{~b})$ turned out to be nanocrystalline ceria particles. Despite the scarcity of identified gold particles, about $2 \%$ by weight of gold was found in the region in Figure 1(a) by EDS, indicating that gold was indeed present at the expected concentration, probably in the form of clusters that were too small to be observed or even atomically dispersed. Many more gold particles with an average diameter of 3-5 nm were found dispersed throughout the other two samples, especially for $\mathrm{Au} / \mathrm{CeO}_{2}-500$.

\subsection{Surface chemical state}

The surface concentration of $\mathrm{Au}, \mathrm{Ce}$ and $\mathrm{O}$ and the distribution of the different $\mathrm{Au}$ species are summarized in Table 1. The Au $4 \mathrm{f}$ spectra of the catalysts, with binding energy corrected for charging effect using the $917 \mathrm{eV}$ Ce u'" peak as internal binding energy reference, are shown in Figure 2. The binding energies of $\mathrm{Au} 4 \mathrm{f}_{7 / 2}$ were 84.6 $\mathrm{eV}, 83.8 \mathrm{eV}$ and $83.6 \mathrm{eV}$ for $\mathrm{Au} / \mathrm{CeO}_{2}-100, \mathrm{Au} / \mathrm{CeO}_{2}-$ 300 and $\mathrm{Au} / \mathrm{CeO}_{2}-500$ respectively. The binding energy difference shows that the chemical state of $\mathrm{Au}$ is affected by the nature of the ceria support. To quantify the difference, the Au $4 \mathrm{f}$ spectra were

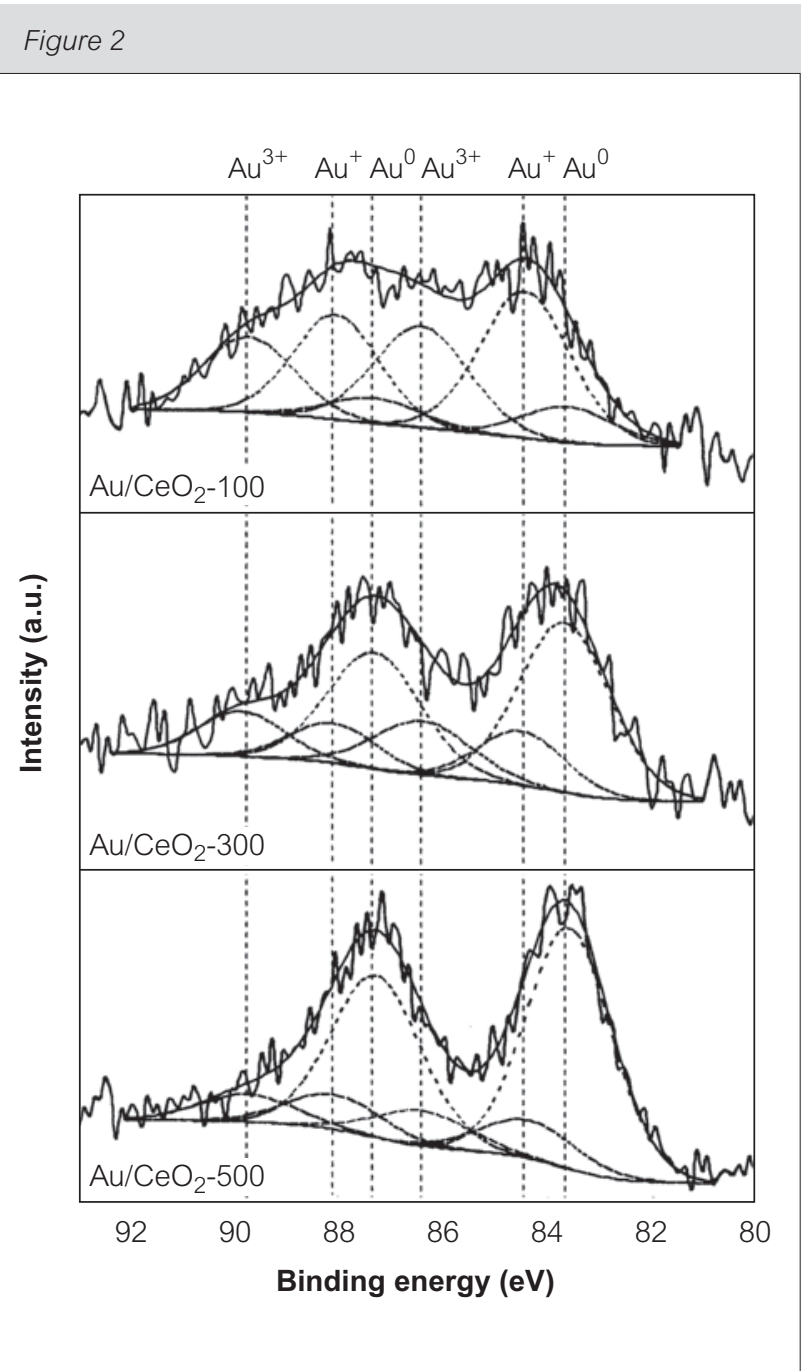

XPS profiles of Au $4 f$ region for $\mathrm{Au} / \mathrm{CeO}_{2}$ samples 
resolved into 3 doublets corresponding to $A u^{0}\left(4 f_{7 / 2}\right.$ B.E. at $83.6 \mathrm{eV}), \mathrm{Au}^{+}\left(4 \mathrm{f}_{7 / 2}\right.$ B.E. at $\left.84.4 \mathrm{eV}\right)$ and $\mathrm{Au}^{3+}$ $\left(4 \mathrm{f}_{7 / 2}\right.$ B.E. at $\left.86.4 \mathrm{eV}\right)$.

Cationic gold species were dominant in $\mathrm{Au} / \mathrm{CeO}_{2}-100$ while mainly metallic gold was found in $\mathrm{Au} / \mathrm{CeO}_{2}-300$ and $\mathrm{Au} / \mathrm{CeO}_{2}-500$. As listed in Table 1, the fraction of metallic gold increased with the rise in calcination temperature of $\mathrm{CeO}_{2}$. Based on the HRTEM and XPS results, we suggested that gold mainly existed as highly dispersed cationic species on the surfaces of $\mathrm{CeO}_{2}-100$, whereas metallic gold particles were the main gold species in $\mathrm{Au} / \mathrm{CeO}_{2}-500$. Since the same

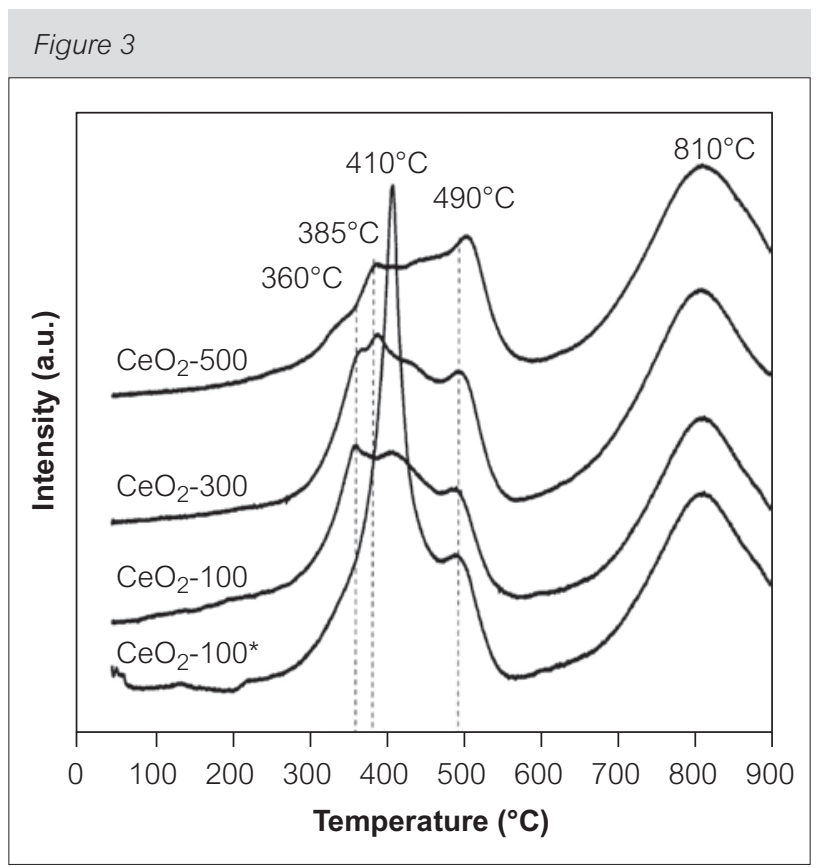

$\mathrm{H}_{2}$-TPR profiles of $\mathrm{CeO}_{2}$ catalysts $\left(\mathrm{CeO}_{2}-100^{*}\right.$ : sample without pre-oxidation at $300^{\circ} \mathrm{C}$ in air before $\mathrm{TPR}^{2}$ experiment) deposition-precipitation condition was adopted, the appearance of different gold species among the three samples must originate from the different thermal treatment of the $\mathrm{CeO}_{2}$ support.

\subsection{Temperature programmed hydrogen reduction}

The redox behaviors of the $\mathrm{CeO}_{2}$ materials and goldcontaining samples were studied by $\mathrm{H}_{2}$-TPR and the results are shown in Figures 3 and 4 . Two sets of peaks representing the reduction of surface-capping oxygen and bulk phase lattice oxygen were found for $\mathrm{CeO}_{2}$ materials (16). The reduction peak temperature

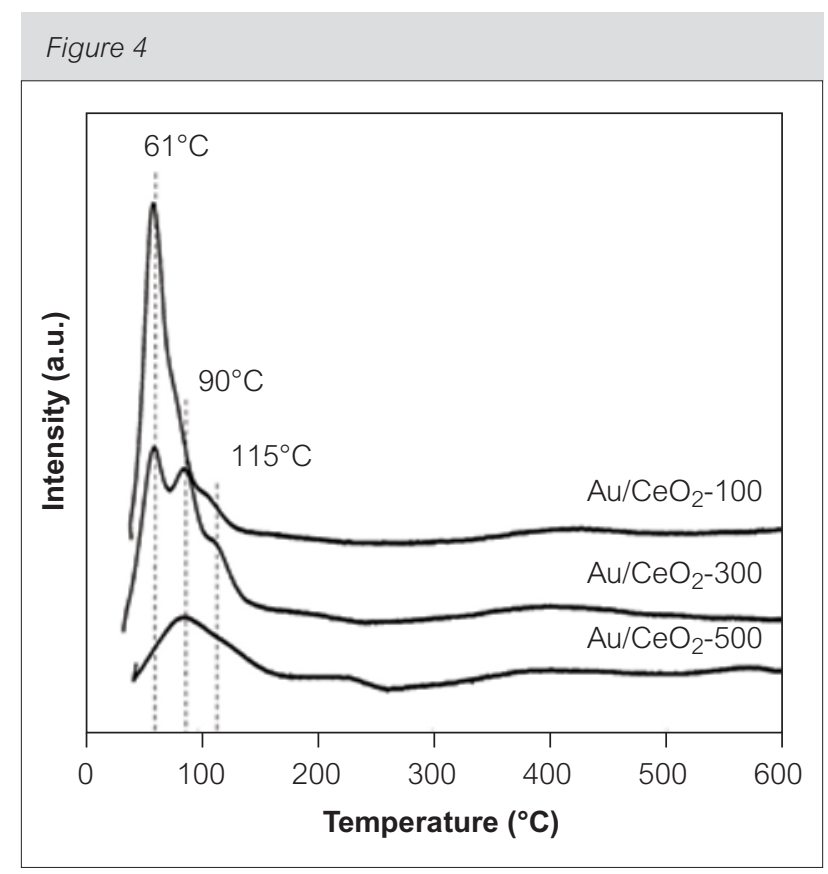

$H_{2}$-TPR profiles of gold-containing samples

Table 2: $\mathrm{H}_{2}$-TPR results of different samples

\begin{tabular}{|c|c|c|c|}
\hline Catalyst & $\begin{array}{l}\text { Peak } \\
\text { temperature } \\
\left({ }^{\circ} \mathrm{C}\right)\end{array}$ & $\begin{array}{l}\mathrm{H}_{2} \text { consumption for surface } \\
\text { oxygen reduction up to } 550^{\circ} \mathrm{C} \\
\left(\mu \mathrm{mol} / \mathrm{g}_{\text {cat }}\right)\end{array}$ & $\begin{array}{l}\text { " } x \text { " in } \mathrm{CeO}_{\mathrm{x}} \text { after } \mathrm{H}_{2} \\
\text { reduction to } 550^{\circ} \mathrm{C}\end{array}$ \\
\hline $\mathrm{CeO}_{2}-100^{*}$ & $300-550$ & 794 & 1.86 \\
\hline $\mathrm{CeO}_{2}-300$ & $300-550$ & 742 & 1.87 \\
\hline $\mathrm{CeO}_{2}-500$ & $300-550$ & 683 & 1.88 \\
\hline $\mathrm{Au} / \mathrm{CeO}_{2}-100$ & $61-107,500$ & $1169\left(977^{a}\right)$ & 1.80 \\
\hline $\mathrm{Au} / \mathrm{CeO}_{2}-300$ & $62-140,500$ & $1247\left(1029^{a}\right)$ & 1.80 \\
\hline $\mathrm{Au} / \mathrm{CeO}_{2}-500$ & $62-210,500$ & $951\left(569^{a}\right)$ & 1.84 \\
\hline
\end{tabular}


and corresponding hydrogen consumption for the surface reduction peaks below $550^{\circ} \mathrm{C}$ are listed in Table 2. With the gold-containing samples the amount of $\mathrm{H}_{2}$ consumption at temperature below $250^{\circ} \mathrm{C}$ are given in brackets.

$\mathrm{CeO}_{2}-100^{*}$ gave two reduction peaks at $410^{\circ} \mathrm{C}$ and $490^{\circ} \mathrm{C}$. The TPR profiles of $\mathrm{CeO}_{2}-100, \mathrm{CeO}_{2}-300$ and $\mathrm{CeO}_{2}-500$ are quite different. As all three samples had undergone pre-oxidation in air at $300^{\circ} \mathrm{C}$ for $1 \mathrm{~h}$, they should be considered as samples after calcination at increasing severity. The most significant differences of the calcined samples compared to $\mathrm{CeO}_{2}-100^{*}$ are (i) the increase in prominence of the $490^{\circ} \mathrm{C}$ peak, which also shifted to a higher peak temperature around $500^{\circ} \mathrm{C}$ on increasing calcination severity, (ii) the reduction in intensity of the $410^{\circ} \mathrm{C}$ peak, and (iii) the concomitant appearance of peaks at 360 and $385^{\circ} \mathrm{C}$. Reduction of ceria surface at around $500^{\circ} \mathrm{C}$ was well documented in the literature, especially for well-calcined nanocrystalline ceria $(17,18)$. It is well known that the (111) plane is thermodynamically the most stable (19). With calcination, well defined facets bound by stable low-index planes is expected to develop and (111) facets eventually would become the most prominent exposed surface. Hence we attribute the $500^{\circ} \mathrm{C}$ peak to reduction of (111) surfaces. The 360 and $385^{\circ} \mathrm{C}$ peaks were attributed to corners and edges at the boundary of the crystallite facets. The broad feature in between we attribute to reduction of the less stable (110) and (100) facets of the crystallites. As $\mathrm{CeO}_{2}-100^{*}$ was not calcined, its surface should be more disordered and contained more defects. Hence, we ascribe the peak at $410^{\circ} \mathrm{C}$ to the reduction of poorly crystalline ceria surfaces.

With the addition of $\mathrm{Au}$, the main part of the lowtemperature reduction peak shifted to the much lower temperature of $60-120^{\circ} \mathrm{C}$. Since the amount of $\mathrm{H}_{2}$ required to reduce $\mathrm{Au}^{\delta+} \rightarrow \mathrm{Au}^{0}$ over these catalysts is less then $140 \mu \mathrm{mol} / \mathrm{g}$, much less than the $\mathrm{H}_{2}$ consumed below $250^{\circ} \mathrm{C}$, we ascribe the low temperature reduction peaks to the reduction of gold-activated ceria surface. For $\mathrm{Au} / \mathrm{CeO}_{2}-100$, a main reduction peak at $61^{\circ} \mathrm{C}$ with two shoulder peaks at about $82^{\circ} \mathrm{C}$ and $115^{\circ} \mathrm{C}$ were observed, whereas two peaks of similar height at $61^{\circ} \mathrm{C}$ and $90^{\circ} \mathrm{C}$ with a relatively weaker peak at $115^{\circ} \mathrm{C}$ were found for $\mathrm{Au} / \mathrm{CeO}_{2}-300$. $\mathrm{Au} / \mathrm{CeO}_{2}-500$ showed only one broad peak in the $50-140^{\circ} \mathrm{C}$ range. It is known that metallic gold in analogy with other noble metals may activate hydrogen that spillover to nearby ceria, thus promoting the reduction of ceria at lower temperature (20). For highly dispersed $\mathrm{Au} / \mathrm{CeO}_{2}$, reduction peak at $60-180^{\circ} \mathrm{C}$ had been reported, with lower reduction temperature indicating stronger interaction between gold and the support (19, 21-23). In our experiment, the existence of three reduction peaks might indicate that the different gold species identified by XPS activate surface oxygen for reduction in slightly different manners.

Data in Table 2 show that the $\mathrm{H}_{2}$ consumption for Au-containing samples was higher than that for pure $\mathrm{CeO}_{2}$ by amount more than that required to reduce ionic gold, suggesting that some sub-surface ceria was reduced after the addition of gold.

\subsection{Catalytic activity}

The catalytic activity of $\mathrm{CeO}_{2}$ and $\mathrm{Au} / \mathrm{CeO}_{2}$ for isobutane oxidation is shown in Figure 5. Carbon dioxide and water were the only detected products and carbon mass balance was higher that 95\%. Isobutane oxidation activity over the gold-free samples is similar. This could be understood since all samples were activated by air at $300^{\circ} \mathrm{C}$ for $2 \mathrm{~h}$ before the reaction and TPR data showed that the surfaces were rather similar after such activation.

Gold enhanced the isobutane oxidation activity significantly. At $350^{\circ} \mathrm{C}$, while the isobutane conversion over all three $\mathrm{CeO}_{2}$ supports was

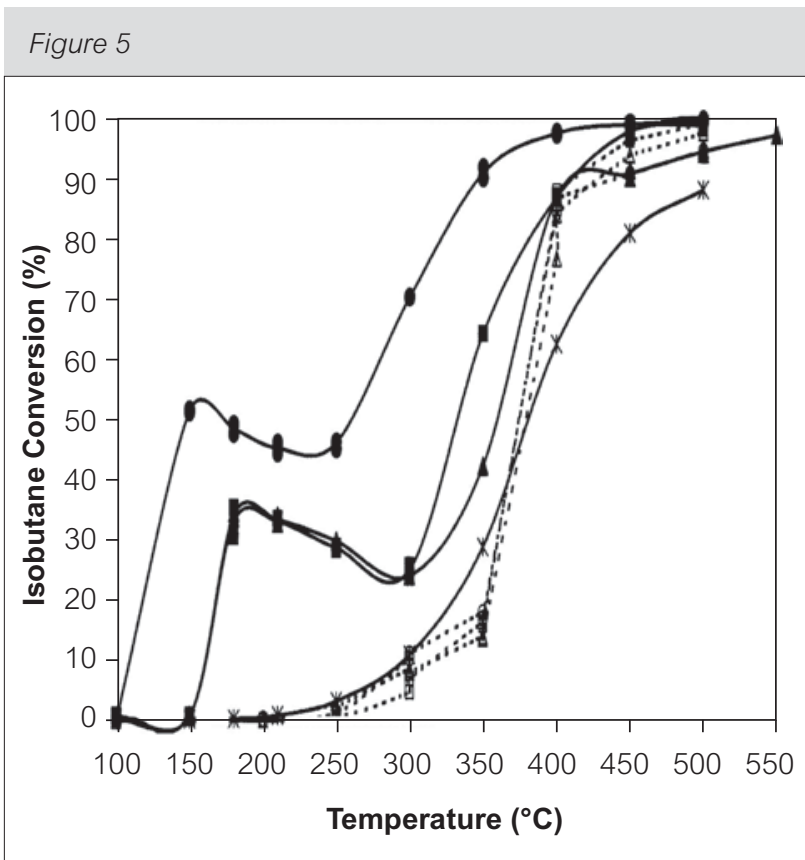

(a) Activity for isobutane oxidation over different catalysts.

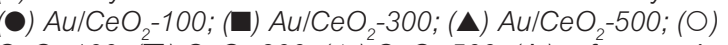

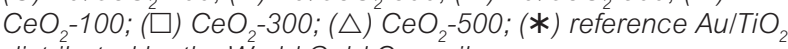
distributed by the World Gold Council 
Table 3: Surface composition of the catalysts after reaction under different conditions

\begin{tabular}{|c|c|c|c|c|c|c|c|c|}
\hline \multirow[t]{2}{*}{ Catalyst } & \multicolumn{4}{|c|}{ Surface composition } & \multirow{2}{*}{$\begin{array}{l}\text { Position of } \\
\text { Au } \mathbf{4 f}_{7 / 2} \text { peak }\end{array}$} & \multicolumn{3}{|c|}{ Au species distribution } \\
\hline & $\begin{array}{l}\mathrm{Au} \\
(\mathrm{mol} \%)\end{array}$ & $\begin{array}{l}\mathrm{Ce} \\
(\mathrm{mol} \%)\end{array}$ & $\begin{array}{l}\mathrm{O} \\
(\mathrm{mol} \%)\end{array}$ & $\mathrm{Au} / \mathrm{Ce}$ & & $\begin{array}{l}\mathrm{Au}^{0} \\
(\%)\end{array}$ & $\begin{array}{l}\mathrm{Au}^{+} \\
(\%)\end{array}$ & $\begin{array}{l}\mathrm{Au}^{3+} \\
(\%)\end{array}$ \\
\hline \multirow{7}{*}{$\begin{array}{l}\mathrm{Au} / \mathrm{CeO}_{2}-100 \\
\mathrm{Au} / \mathrm{CeO}_{2}-100(180) \\
\mathrm{Au} / \mathrm{CeO}_{2}-100(280) \\
\mathrm{Au} / \mathrm{CeO}_{2}-100(500) \\
\mathrm{Au} / \mathrm{CeO}_{2}-100(500-180) \\
\mathrm{Au} / \mathrm{CeO}_{2}-100(500-30) \\
\mathrm{Au} / \mathrm{CeO}_{2}-100(180)^{*}\end{array}$} & 0.45 & 28.2 & 71.3 & 0.016 & 84.6 & 13.0 & 50.1 & 36.9 \\
\hline & 0.37 & 31.6 & 68.1 & 0.012 & 84.0 & 54.0 & 32.6 & 13.4 \\
\hline & 0.31 & 29.9 & 69.8 & 0.010 & 83.8 & 72.4 & 14.2 & 13.4 \\
\hline & 0.16 & 23.8 & 76.1 & 0.007 & 83.6 & 75.8 & 1.4 & 22.8 \\
\hline & 0.25 & 28.7 & 71.1 & 0.009 & 83.7 & 68.9 & 10.5 & 20.6 \\
\hline & 0.26 & 32.8 & 67.0 & 0.008 & 83.9 & 46.0 & 24.6 & 29.4 \\
\hline & 0.21 & 27.0 & 72.8 & 0.008 & 83.7 & 64.9 & 13.5 & 21.6 \\
\hline \multicolumn{9}{|c|}{$\begin{array}{l}\mathrm{Au} / \mathrm{CeO}_{2}-100(180) \text { : catalyst was treated at } 180^{\circ} \mathrm{C} \text { under reaction condition for } 1 \mathrm{~h} \text {, then cooled down in } \\
\mathrm{N}_{2} \text { to room temperature. }\end{array}$} \\
\hline \multicolumn{9}{|c|}{$\begin{array}{l}\mathrm{Au} / \mathrm{CeO}_{2}-100(500-180) \text { : catalyst was first used in isobutane oxidation at temperature from } 200-500^{\circ} \mathrm{C} \text {, then } \\
\text { cooled down to } 180^{\circ} \mathrm{C} \text { in the reactant stream and maintained at } 180^{\circ} \mathrm{C} \text { for } 1 \mathrm{~h} \text { before finally cooled down to room } \\
\text { temperature in } \mathrm{N}_{2} .\end{array}$} \\
\hline \multicolumn{9}{|c|}{$\mathrm{Au} / \mathrm{CeO}_{2}-100(180)^{*}$ : catalyst after stability test at $180^{\circ} \mathrm{C}$, cooled down in $\mathrm{N}_{2}$ to room temperature. } \\
\hline
\end{tabular}

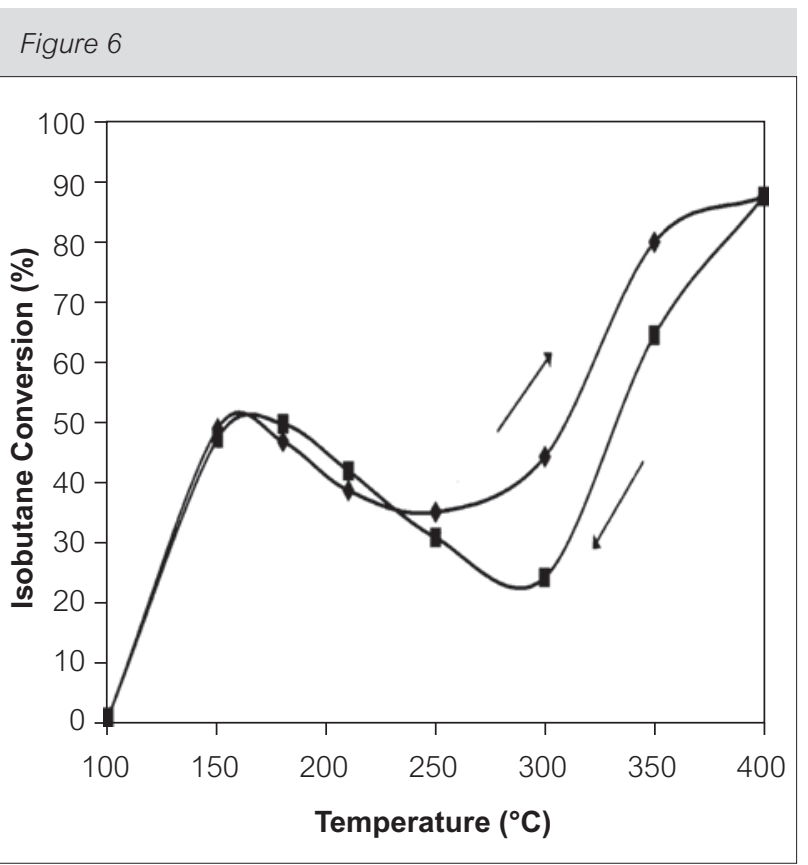

Catalytic activity of $\mathrm{Au} / \mathrm{CeO}_{2}-100$ determined when the reaction temperature was increased $(\bullet)$ and decreased $(\mathbf{\square})$ in the reactant stream

between 10-20\%, the conversion over $\mathrm{Au} / \mathrm{CeO}_{2}-500$, $\mathrm{Au} / \mathrm{CeO}_{2}-300$ and $\mathrm{Au} / \mathrm{CeO}_{2}-100$ were increased to $42 \%, 64 \%$ and $91 \%$ respectively. More interestingly, for the Au-containing catalysts, an additional low-temperature volcano-shaped activity profile was found. Isobutane conversion increased with increasing reaction temperature up to $150-180^{\circ} \mathrm{C}$; the activity then declined with increasing temperature between 180 and $300^{\circ} \mathrm{C}$. Further increase of temperature resulted in rise in isobutane conversion again. For comparison, we carried out the isobutane oxidation reaction over the A-type reference $\mathrm{Au} / \mathrm{TiO}_{2}$ catalyst supplied by the World Gold Council. The reference $\mathrm{Au} / \mathrm{TiO}_{2}$ showed isobutane oxidation activity similar to that of the ceria supports; the low-temperature activity was completely absent. The reference catalyst has highly dispersed gold and very high activity for $\mathrm{CO}$ oxidation. Complete oxidation of $1 \% \mathrm{CO}$ to $\mathrm{CO}_{2}$ in air was found in our laboratory at room temperature. Hence, we infer that having highly dispersed gold is not a sufficient condition for low temperature isobutane oxidation activity. Our Au/CeO${ }_{2}$ catalysts all contain some cationic gold, and $\mathrm{Au} / \mathrm{CeO}_{2}-100$, the catalyst showing the highest low temperature activity, possesses the highest proportion of cationic gold. Thus, it is logical to ascribe the isobutane oxidation activity to cationic gold species.

To examine the temperature effect more thoroughly, we studied the isobutane activity of a fresh sample 


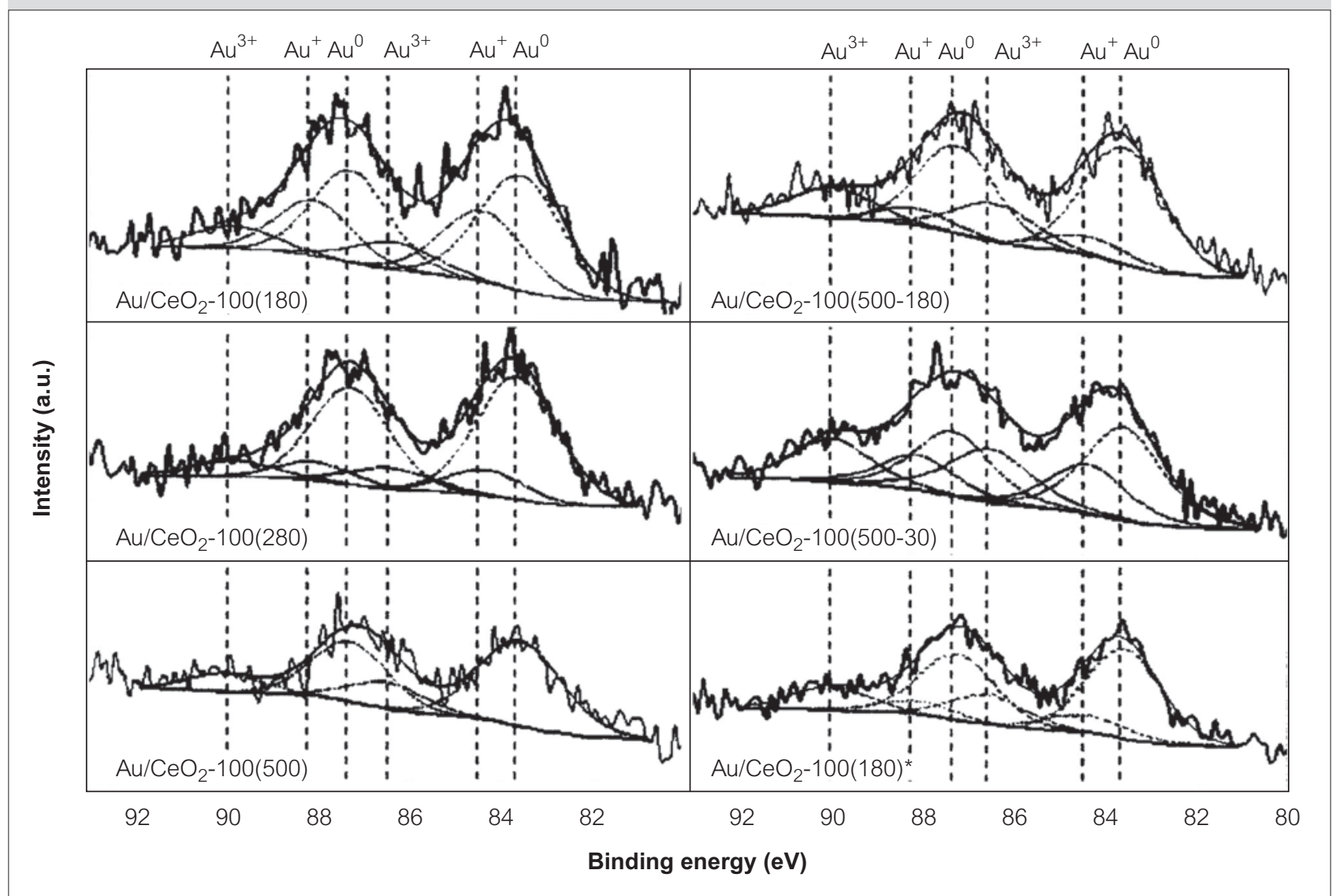

XPS profiles of $\mathrm{Au} 4 \mathrm{f}$ region on $\mathrm{Au} / \mathrm{CeO}_{2}-100$ after various treatments. $\mathrm{Au} / \mathrm{CeO}_{2}(\mathrm{~T})$ : the sample was treated in the reactant stream at $T^{\circ} \mathrm{C}$ for $1 \mathrm{~h}$, then cooled in $\mathrm{N}_{2}$ to room temperature before analysis by XPS; Au/CeO ${ }_{2}(500-T)$ : After exposure to the reactant at $500^{\circ} \mathrm{C}$, the sample was cooled down to $T^{\circ} \mathrm{C}$ in reactant gas and finally cooled in $\mathrm{N}_{2}$ to room temperature before analysis by XPS. $\mathrm{Au} / \mathrm{CeO}_{2}-100(180)^{*}$ : catalyst after stability test at $180^{\circ} \mathrm{C}$, cool down in $\mathrm{N}_{2}$ to room temperature

of the most active catalyst, $\mathrm{Au} / \mathrm{CeO}_{2}-100$ with the temperature of the catalyst bed raised stepwise from $100^{\circ} \mathrm{C}$ to $400^{\circ} \mathrm{C}$. Without reactivation, the temperature of the catalyst bed was then lowered to $100^{\circ} \mathrm{C}$ stepwise while the activity was monitored. The result in Figure 6 showed that a hysteresis loop of activity versus temperature appeared at temperature higher than $250^{\circ} \mathrm{C}$, suggesting that the catalyst was deactivated. However, when the temperature fell below $250^{\circ} \mathrm{C}$, the low-temperature conversion was recovered. From this observation, we infer that self poisoning by the accumulation of strongly adsorbing reaction products such as surface carbonate is not the cause of the catalyst deactivation between 150 and $250^{\circ} \mathrm{C}$ since desorption of such species leading to reactivation could not happen when the catalyst bed temperature was lowered. Furthermore, a sample of the catalysts was subjected to prolonged reaction at $180^{\circ} \mathrm{C}$. Isobutane conversion increased slightly from $50 \%$ to around $55 \%$ in the first five hours and then maintained more or less constant in the next 90 hours. The absence of catalyst deactivation at constant temperature further ruled out poisoning by adsorbed reaction products. Reversible change in the chemical nature of the catalyst surface is a more probable reason for the peculiar behavior of the catalysts for isobutane oxidation.

\subsection{The importance of cationic gold in isobutane oxidation reactions}

Activity hysteresis loop was also observed by Zhang et al. on $\mathrm{AuO}_{x} / \mathrm{Ce}_{0.6} \mathrm{Zr}_{0.3} \mathrm{Y}_{0.1} \mathrm{O}_{2}$ catalysts in methane oxidation (24). They suggested that the hysteresis loop was caused by the partial reduction of the more active $\mathrm{AuO}_{\mathrm{x}}$ to less active $\mathrm{Au}^{0}$ as well as the $\mathrm{Ce}^{4+}$ in CZY to $\mathrm{Ce}^{3+}$ at high temperature. Similarly, for methane oxidation over $\mathrm{Pd}$, deactivation at high temperature due to decomposition of the more active $\mathrm{Pd}-\mathrm{O}$ and reactivation at low temperature by reoxidation of $\mathrm{Pd}$ was known (25). 
With this background in mind, we performed ex-situ XPS measurement of the catalysts surface in an attempt to elucidate how the surface chemical state of the catalyst changes during the reaction.

Samples of $\mathrm{Au} / \mathrm{CeO}_{2}-100$ were exposed to the reaction gas mixture at different temperatures for about $35 \mathrm{~min}$. To preserve the surface condition, the samples were cooled to room temperature in a stream of nitrogen before XPS analysis. We denote these samples as $\mathrm{Au} / \mathrm{CeO}_{2}-100(\mathrm{~T})$ where $\mathrm{T}$ is the temperature of exposure in ${ }^{\circ} \mathrm{C}$ of the catalyst to the reactant gas. To study the reversibility of the oxidation state change, two catalyst samples were first heated to $500^{\circ} \mathrm{C}$ and then cooled in the reactant gas to $180^{\circ} \mathrm{C}$ and $30^{\circ} \mathrm{C}$ before switching to nitrogen flow. These samples were denoted as $\mathrm{Au} / \mathrm{CeO}_{2}-100(500-$ 180) and $\mathrm{Au} / \mathrm{CeO}_{2}-100(500-30)$. The catalyst after prolonged reaction at $180^{\circ} \mathrm{C}$ for $100 \mathrm{~h}$ was also analyzed and denoted as $\mathrm{Au} / \mathrm{CeO}_{2}-100(180)^{*}$. The XPS analysis results are summarized in Table 3 and the Au $4 \mathrm{f}$ spectra are shown in Figure 7. The fraction of gold in the metallic state increased with temperature increase from 180 to $280^{\circ} \mathrm{C}$ under the reaction condition. There is a correlation between the cationic gold content and isobutane oxidation activity - the activity decreased along with the gold reduction. After carefully examining the XPS data, we found that the change of $\mathrm{Au}^{+}$and $\mathrm{Au}^{3+}$ are quite different. When the reaction temperature changed from 180 to $280^{\circ} \mathrm{C}$, the concentration of $\mathrm{Au}^{3+}$ was almost unchanged while $\mathrm{Au}^{+}$was diminished by almost $56 \%$. After reaction at $500^{\circ} \mathrm{C}, \mathrm{Au}^{+}$species could hardly be detected. On the catalysts that were cooled in the reactant gas after $500^{\circ} \mathrm{C}$ treatment, a partial recovery of the $\mathrm{Au}^{+}$concentration with decreasing temperature was observed although the degree of gold oxidation over the fresh catalyst was never recovered. On the other hand, the variation of $\mathrm{Au}^{3+}$ with temperature was more irregular. While reaction at $500^{\circ} \mathrm{C}$ nearly completely eliminated $\mathrm{Au}^{+}$ from the catalyst surface, significant amount of $\mathrm{Au}^{3+}$ remained. From the observation, we deduced that the low-temperature activity is associated with $\mathrm{Au}^{+}$ whereas the enhancement of the catalytic activity above $300^{\circ} \mathrm{C}$ is associated with $\mathrm{Au}^{3+}$.

\subsection{Origin of the active sites for isobutane oxidation}

We have associated low-temperature isobutane oxidation activity to $\mathrm{Au}^{+}$species. The $\mathrm{Au}-\mathrm{CeO}_{2}-100$, prepared from uncalcined $\mathrm{CeO}_{2}-100$, was revealed by $\mathrm{H}_{2}-\mathrm{TPR}$ to have disordered surface. This same sample contains a much higher fraction of $\mathrm{Au}^{+}$and
$\mathrm{Au}^{3+}$ compared to those supported on the $\mathrm{CeO}_{2}-300$ and $\mathrm{CeO}_{2}-500$ with better crystallinity. We infer that both $\mathrm{Ce}$ and $\mathrm{O}$ vacancies exist at high concentration over $\mathrm{CeO}_{2}-100$ and the former acts as sites for trapping substitutional $\mathrm{Au}^{3+}$ while the latter stabilizing small monolayer $\mathrm{Au}^{+}$clusters.

Reduction of such $\mathrm{Au}^{+}$species to $\mathrm{Au}^{0}$ during reaction at increasing temperature should be accompanied by transformation of monolayer Au clusters into thicker multilayer Au particles. Data shown in Table 3 revealed that surface concentration of $\mathrm{Au}$ was highest on the fresh $\mathrm{Au} / \mathrm{CeO}_{2}-100$ sample. The surface Au/Ce ratio dropped significantly from 0.016 on the fresh catalyst to 0.007 on the catalyst after reaction at $500^{\circ} \mathrm{C}$, suggesting that an increase in the thickness of the Au clusters had indeed occurred. However, on cooling the catalyst from $500^{\circ} \mathrm{C}$ to $30^{\circ} \mathrm{C}$, the regeneration of the $\mathrm{Au}^{+}$species was not accompanied by redispersion of Au. The surface Au/Ce ratio remained in the 0.007 to 0.009 range. If the Au particles remained in the multilayer structure, then conversion of $\mathrm{Au}^{0}$ to $\mathrm{Au}^{+}$has to be attributed to oxidation of the multilayer Au clusters. On closer examination of the surface chemical characteristic of $\mathrm{Au} / \mathrm{CeO}_{2}-100(180)$ and $\mathrm{Au} / \mathrm{CeO}_{2}-100(180)^{*}$, we note that with increasing time of reaction from 1 hour to 100 hours, the surface Au/Ce ratio decreased from 0.012 to 0.008 , and the fraction of $\mathrm{Au}^{+}$decreased from $32.6 \%$ to $13.5 \%$. During the first $5 \mathrm{~h}$ of reaction at this temperature, the conversion of isobutane showed a slight increase, in apparent contradiction to our deduction that $\mathrm{Au}^{+}$is the active species for oxidation of butanes. This suggested that rather than the initially present positively charged monolayer Au clusters, surface gold oxide that formed during the reaction is the active species. That low-temperature isobutane oxidation observed on $\mathrm{Au} / \mathrm{CeO}_{2}$ but not on the reference $\mathrm{Au} / \mathrm{TiO}_{2}$ catalyst highlights the role of $\mathrm{CeO}_{2}$. We propose that ceria adjacent to the very small gold particles supplies reactive oxygen to gold for isobutane oxidation as well as maintaining the gold surface oxidized.

At high temperature, oxidation of hydrocarbon over transition metal oxide is often assumed to involve the participation of lattice oxygen (26-29). We suggest that above $300^{\circ} \mathrm{C}$, the promotion effect of gold is due to substitutional $\mathrm{Au}^{3+}$ reducing the $\mathrm{Ce}-\mathrm{O}$ bond strength and hence increasing the rate of butane oxidation. 


\section{Conclusions}

Results of this work suggest that uncalcined high surface area ceria possesses high concentration of both cationic and anionic vacancies that stabilized substitutional $\mathrm{Au}^{3+}$ ions and positively charged monolayer gold clusters. Substitutional $\mathrm{Au}^{3+}$ ions weaken the $\mathrm{Ce}-\mathrm{O}$ bond, facilitating the oxidation of isobutane above $300^{\circ} \mathrm{C}$. Monolayer Au clusters were converted into small multilayer gold particles during isobutane oxidation. With a supply of active oxygen from the adjacent ceria support, formation of surface gold oxide provides additional active sites for lowtemperature oxidation of butane not available over the pure ceria support. The most active catalyst in this study gave isobutane conversion about $55 \%$ at the very low temperature of $180^{\circ} \mathrm{C}$. The catalyst showed no sign of deactivation for isobutane oxidation over a period of $100 \mathrm{~h}$.

\section{Acknowledgement}

This work is supported by a Faculty Research Grant from the Hong Kong Baptist University (FRG1/08-09/061).

\section{About the authors}

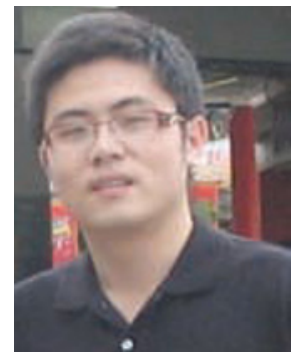

Ying Fang got his master's degree in Physical Chemistry (2007) at the Xiamen University with researches in the field of heterogeneous catalysis. Ying joined Dr. Lai's research group at the Hong Kong Baptist University in Dec 2006 as a PhD student. His present research focuses on the development, synthesis, and

characterization of ceria supported noble metal catalysts for VOCs complete oxidation.

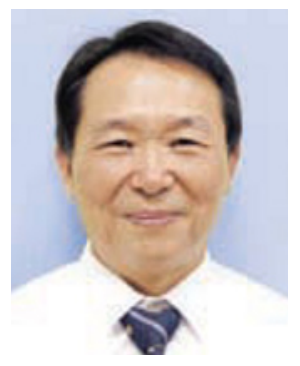

Shuiju Wang is Professor of the State Key Laboratory for Physical Chemistry of Solid Surface at Xiamen University. $\mathrm{He}$ is a member of ISO/TC201 (Surface Chemical Analysis). His research interest is in the physical chemistry of solid surface, micro-nanometer scale structural analysis of materials, and in heterogeneous catalysis.

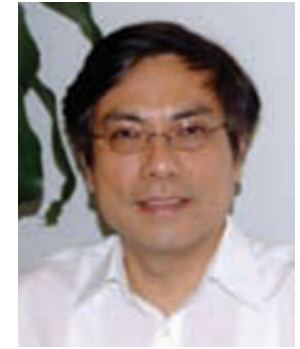

Chak-Tong Au is Professor of Department of Chemistry of the Hong Kong Baptist University. Before joining HKBU in 1990, he did research in the University College, Cardiff, Wales and then joined the Department of Chemistry, Xiamen University in 1986 as associate professor and was promoted to professor in 1987. In 2003, he was awarded D.Sc. degree by the University of Liverpool in recognition of his contributions in the field of surface science and heterogeneous catalysis. At present, he serves as associate editor of the Elsevier journal Applied Catalysis A: General.

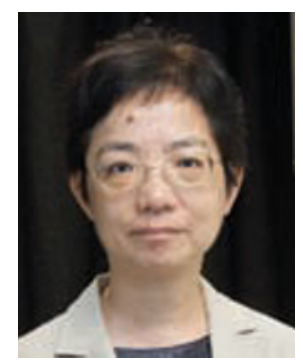

Suk-Yin Lai is Associate Professor at the Department of Chemistry and Director of the Centre for Surface Analysis of the Hong Kong Baptist University. Her research interest is in the application of solid catalysts in pollution abatement and in the application of surface analysis techniques for catalyst characterization.

\section{References}

1 G.C. Bond, and D.T. Thompson, Catal. Rev. Sci. Eng., 1999, 41, 319

2 S.-Y. Lai, Y. Quu, and S. Wang, J. Catal., 2006, 237, 303

3 D. Andreeva, R. Nedyalkova, L. Ilieva, and M.V. Abrashev, Appl. Catal. A: General, 2003, 246, 29

4 C.D. Pina, N. Dimitratos, E. Falletta, M. Rossi and A. Siani, Gold Bull., 2007, 40, 1

5 G. Munteanu, L. Ilieva, R. Nedyalkova and D. Andreeva, Appl. Catal. A: General, 2004, 277, 31

6 S. Scire, S. Minico, C. Crisafulli, C. Satriano and A. Pistone, Appl. Catal. B: Environmental, 2003, 40, 43

7 Y. Shen, X. Yang, Y. Wang, Y. Zhang, H. Zhu, L. Gao and M. Jia, Appl. Catal. B: Environmental, 2008, 79, 142

8 S.Y. Liu and S.M. Yang, Appl. Catal. A: General, 2008, 334, 92

9 Q. Fu, H. Saltsburg and M. Flytzani-Stephanopoulos, Science, 2003, 301, 935

10 S. Carrettin, J. Guzman and A. Corma, Angew Chem, Int Ed, 2005, 44, 2242

11 Z.P. Liu, S.J. Jenkins and D.A. King, Phys. Rev. Lett., 2005, 94, 196102

12 M.F. Camellone and S. Fabris, J. Am. Chem. Soc., 2009, 131, 10473

13 M. Škoda, M. Cabala, I. Matolinová, K.C. Prince, T. Skála, F. Šutara, K. Veltruská and V. Matolín, J. Chem. Phys., 2009, 130, 034703 
14 K. Naya, R. Ishikawa and K. Fukui, J. Phys. Chem. C, 2009, 113, 10726

15 H. Shi and C. Stampfl, Phys. Rev. B, 2007, 76, 075327

16 H.S. Yao, and Y.F.Y. Yao, J. Catal., 1984, 86, 254

17 D. Terribile, A. Trovarelli, C. de Leitenburg, G. Dolcetti and J. Llorca, Chem. Mater., 1997, 9, 2676

18 Y.D. Bi, W. Zhang, H.Y. Xu and W.Z. Li, Catal. Lett., 2007, 119, 126

19 A.M. Venezia, G. Pantaleo, A. Longo, G. DiCarlo, M.P. Casaletto, F.L. Liotta and G. Deganello, J. Phys. Chem. B, 2005, 109, 2821

20 M. Machida, D. Kurogi and T. Kijima, J. Phys. Chem. B, 2002, 107, 196

21 W. Deng, A.I. Frenkel, R. Si and M. Flytzani-Stephanopoulos, J. Phys. Chem. C, 2008, 112, 12834

22 M. Manzoli, F. Boccuzzi, A. Chiorino, F. Vindigni, W. Deng, and M. Flytzani-Stephanopoulos, J. Catal., 2007, 245, 308
23 B.E. Solsona, T. Garcia, C. Jones, S.H. Taylor, A.F. Carley and G.J. Hutchings, Appl. Catal. A: General, 2006, 312, 67

24 Y. Zhang, J. Deng, L. Zhang, W. Qiu, H. Dai and H. He, Catal. Today, 2008, 139, 29

25 D. Ciuparu, M. Lyubovsky, E. Altman, L. Pfefferle and A. Datye, Catal. Rev. - Sci. Eng., 2002, 44, 593

26 S. Minico, S. Scire, C. Crisefulli, R. Maggiore and S. Galvano, Appl. Catal. B: Environmental, 2000, 28, 245

27 S. Zhao and R.J. Gorte, Appl. Catal. A: General, 2003, 277, 129

28 A.C. Gluhoi, N. Bogdanchikova and B.E. Nieuwenhuys, J. Catal., 2005, 229, 154

29 C. Cellier, V. Ruzux, C. Lahousse, P. Grange and E.M. Gaigneaux, Catal. Today, 2006, 117, 350 